\title{
RESPONSE OF CYCAS REVOLUTA THUNB. TRANSPLANTS TO SOME BIO, ORGANIC AND CHEMICAL FERTILIZATION
}

\author{
AMAL A. ZAKY \\ Ornamental Plants Res. and Landscape Dep., Hort. Res. Inst., ARC, Giza, Egypt.
}

(Manuscript received 4 April 2012)

\begin{abstract}
This experiment was performed in the greenhouse at the nursery of the Ornamental Plants Res. and Landscape Dep., Hort. Res. Inst., ARC., Giza, Egypt through two successive seasons (2010 and 2011) to investigate the response of Cycas revoluta Thunb to inoculation with arbuscular mycorrhizal (AM) fungi and Actosol (Acto.) either solely or in a combined mixture as a bio and organic fertilizer in comparison to mineral fertilization (NPK). The obtained results revealed that fertilization treatments significantly stimulated most of the studied characters compared to control. The inoculation of Cycas with either AM fungi and /or Actosol gave the highest values of vegetative growth parameters [leaves length $(\mathrm{cm})$, width $(\mathrm{cm})$, petiole length $(\mathrm{cm})$, number of leaves and pinnae plant $^{-1}$, fresh and dry weights of leaves plant ${ }^{-1}(\mathrm{~g})$ ] as well as root length, fresh and dry weights. Inoculation with AM fungi followed by Actosol markedly improved chlorophyll a, b and carotenoids and gave the highest total carbohydrates $\%$ in leaves. Likewise, all fertilization treatments greatly raised the percentage of $\mathrm{N}, \mathrm{P}$ and $\mathrm{K}$ in the leaves, as reached the maximum by AM fungi. The addition of half dose of mineral fertilization ( $1 / 2$ NPK) plus the inoculation with either AM fungi or Actosol were the best compared to full dose NPK solely for all studied parameters of Cycas plant. In general, the dominance in all previous measurements was for AM fungi followed by Actosol+ AM fungi which gave the highest values in most cases.
\end{abstract}

Key words: Cycas, Arbuscular Mycorrhizal fungi (AMF), Actosol (Acto.), NPK.

\section{INTRODUCTIN}

The subtropical Cycas revoluta Thunb- "king sago palm tree" belongs to Cycadaceae family, it is native to the Far East which occurs from Madagascar to Japan and has been used as a choice container and landscape plant for centuries. The growth habit of Cycas revoluta displays an upright trunk with a diameter from 1" to 12 " depending on age, topped with stiff feather-like leaves growing in a circular pattern which has led to the common name "Sago Palm". This subtropical plant adapts to a wide range of temperatures from 15 to 110 degrees $F$ ( -11 to 42 degrees ${ }^{\circ} \mathrm{C}$ ), accepts full sun or bright interior light, thrives with attention, and tolerates neglect. In addition, Cycads are extremely long-lived. Regardless of age or size, Cycas revoluta is one of the easiest plants to grow, indoors or out, by beginner or expert. 
The plant is one of the most primitive living seed plants, and is very unusual and excellent popular foliage ornamental for indoor decoration as used to grace the large rooms and halls of stately homes and mansions, excellent container plant for the decoration of outdoor areas such as verandahs, terraces, the larger species make graceful subjects for landscape use and are often seen planted around public buildings and as lawn specimens. Cycas is used as a source of food starch, producing gum, oils and fibers exhibit a root nodule symbiosis with nitrogen fixing cyano-bacteria, has a great potential value as antimicrobial and natural source of pesticidal biochemicals.

Organic or biofertilizers are from paramount importance for their beneficial effects on the physical, chemical and biological properties of soil organic matter, cation exchange capacity, availability of mineral nutrients to plant to increase productivity. Using Actosol containing humic acid seems to be valuable in correcting the widespread occurrence of certain nutrient deficiency symptoms. This is attained through increasing the soil water holding capacity, promoting soil structure and enhancing the metabolic activity of micro organisms. Humic acid is an excellent root stimulator, increases the permeability of plant membranes and accelerates cell division. It has been shown to increase the uptake of nitrogen, potassium, calcium, magnesium and phosphorus by plants (Brunetti, 2006). Moreover, Stevenson (1994) concluded that humic substances isolated from different materials contained $45-65 \%$ carbon, $30-48 \%$ oxygen, $2-6 \%$ nitrogen and about $5 \%$ hydrogen. Humic substances (HS) are extremely important soil components because they constitute a stable fraction of carbon $(C)$, thus regulating the carbon cycle and release of nutrients including nitrogen $(\mathrm{N})$, phosphorus $(\mathrm{P})$ and Sulphur $(\mathrm{S})$. Additionally, the presence of HS improves $\mathrm{pH}$ buffering and thermal insulation. Arbuscular mycorrhizal (AM) fungus can increase plant growth and quality of most plant species by enhancing water absorption and uptake of nutrients: e.g. phosphorus, potassium and nitrogen as well as $\mathrm{Zn}, \mathrm{Cu}, \mathrm{S}, \mathrm{B}$ and Mo., reduces uptake of toxic heavy metals e.g. manganese, improves soil structure and aggregation. It may affect plant water relationships leading to healthy plants. Mycorrhiza increased availability of nutrients especially phosphorus due to their metabolic activity of AM roots, particularly with plants grown on high phosphate-fixing soil (Saleh et. al., 2008). Chemical fertilizers are an important source of plant nutrients, however, are expensive and cause accumulation of harmful residual substances in plants.

The goal of this research work was undertaken to use natural safety environmental materials (mycorrhizal fungi and humic acid) for their beneficial effects on plant growth and avoid the harmful effects caused by synthetic fertilizers through decreasing the use of NPK and costs requirements for Cycas revoluta plant. 


\section{MATERIALS AND METHODS}

This study was carried out at the Experimental Green house (seran) of the Ornamental Plants Res. and Landscape Dep., Horticultural Research Institute, Agricultural Research Center, Giza, Egypt during two successive seasons (2010 and 2011). Cycas revoluta plants were purchased from a commercial farm with average height 7-10 cm and 2-3 leaves/ plant. On 1st January 2010 and 2011, the plants were individually planted in $25 \mathrm{~cm}$ plastic pots filled with a mixture of clay: sand: peat $(1: 1: 1, v / v / v)$. Physical and chemical analysis of the used soil is presented in Tables (a) and (b). Plants were treated as follows during the growth season:

1- Control.

2- NPK [kristalon (19-19-19) applied at monthly interval either at the rate of $5 \mathrm{~g} / \mathrm{pot}$ as full dose or as $2.5 \mathrm{~g} /$ pot combined with other treatments].

3- Arbuscular mycorrhizal fungi (AMF) [a mixture of mycorrhizal spores which was prepared from the rhizosphere by wet sieving and decanting (Gerdemann and Nicolson, 1963). (AMF) inoculants consisted of $10 \mathrm{ml}$ of wet-sieving suspension of (AMF) containing $50-60$ spores $\mathrm{ml}^{-1}$.The application was at planting as a soil drench.

4- Actosol (Acto.) is a commercial liquid organic fertilizer containing $2.9 \%$ humic acid and $0.5 \%$ for each of $\mathrm{Fe}, \mathrm{Zn}, \mathrm{Mn}$ and $\mathrm{Cu}$ and was applied monthly at $30 \mathrm{~cm}^{3} / \mathrm{I}$ as a soil drench $\left(50 \mathrm{~cm}^{3} /\right.$ pot).

5- $1 / 2$ NPK + Acto.

6- $1 / 2 \mathrm{NPK}+\mathrm{AMF}$

7- Acto. +AMF

\section{Measurements}

1- Vegetative growth characters:

- Leaves length $(\mathrm{cm}) . \quad$-Leaves width $(\mathrm{cm}) . \quad$ - Petiole length $(\mathrm{cm}) . \quad$ - Number of leaves /plant. $\quad$ - Fresh and dry weights of leaves/ plant $(\mathrm{g}) . \quad$-Pinnae number.

2- Root characters:

- Root length $(\mathrm{cm}) . \quad$ - Fresh and dry weights of roots

3- Chemical composition:

- Chlorophyll a, b and carotenoids were determined in fresh leaves (mg/g f.w.) according to Saric et al (1967).

- Total carbohydrates \% in leaves was determined according to Herbert et al., (1971). 
- Nitrogen, phosphorus and potassium \% in leaves were determined according to Jackson (1973).

The layout of the experiment was completely randomized design containing 7 treatments. Each treatment was repeated three times, each replicate contained 6 plants i.e. 18 plants in each treatment.

\section{Statistical analysis:}

All data were subjected to statistical analysis according to the procedure reported by Snedecor and Cochran (1982) and means were compared by New Least Significant Difference (New L.S.D) test at the $5 \%$ level of probability in the two seasons.

Table (a): Physical and chemical analysis of the used soil.

\begin{tabular}{|c|c|c|c|c|c|c|c|c|c|}
\hline \multirow{2}{*}{$\begin{array}{c}\text { Soil } \\
\text { type }\end{array}$} & $\begin{array}{c}\text { Particle } \\
\text { size } \\
(\%)\end{array}$ & \multicolumn{2}{|c|}{$\begin{array}{c}\text { Cations } \\
(\mathrm{meq} / \mathrm{I})\end{array}$} & \multicolumn{2}{|c|}{ Anions(meq)/I } & \multicolumn{2}{|l|}{} \\
\cline { 3 - 10 } & $\mathrm{Ca}^{++}$ & 10.00 & $\mathrm{HCO}^{-3}$ & 1.30 & $\mathrm{~N}$ & $425 \mathrm{ppm}$ & $\begin{array}{c}\mathrm{B.D} \\
\left(\mathrm{g} / \mathrm{cm}^{3}\right)\end{array}$ & $\begin{array}{c}1.25 \\
5\end{array}$ \\
\hline Sandy & 51.39 & $\mathrm{Mg}^{++}$ & 8.02 & $\mathrm{SO}_{4}^{--}$ & 0.30 & $\mathrm{P}$ & $\begin{array}{c}38.0 \\
\mathrm{ppm}\end{array}$ & $\mathrm{WHC}(\%)$ & 46 \\
\hline Silty & 31.63 & $\mathrm{Na}^{+}$ & 1.00 & $\mathrm{Cl}^{-}$ & 0.45 & $\mathrm{~K}$ & $564 \mathrm{ppm}$ & $\mathrm{pH}$ & 7.22 \\
\hline Clayly & 17.98 & $\mathrm{~K}^{+}$ & 0.25 & ----- & ------ & & ----- & E.C(ds /m) & 1.02 \\
\hline
\end{tabular}

Table (b): Chemical analysis of the used peatmoss.

\begin{tabular}{|c|c|c|c|c|c|}
\hline Organic matter & $90-95 \%$ & Water relation capacity & $\begin{array}{c}60-75 \\
\%\end{array}$ & $\mathrm{~K}$ & $1.77 \%$ \\
\hline Ash & $5-10 \%$ & Salinity & $0.3 \mathrm{~g} / \mathrm{I}$ & $\mathrm{Fe}$ & $\begin{array}{c}421 \\
\mathrm{ppm}\end{array}$ \\
\hline Density (Vol.Dry) & $80-90 \mathrm{Mg} / \mathrm{L}$ & $\mathrm{N}$ & $1.09 \%$ & $\mathrm{Mn}$ & $27 \mathrm{ppm}$ \\
\hline pH value & 3.4 & $\mathrm{P}$ & $0.23 \%$ & $\mathrm{Zn}$ & $41 \mathrm{ppm}$ \\
\hline
\end{tabular}

\section{RESULTS AND DISCUSSION}

\section{I- Morphological characters of vegetative growth}

Morphological characters of vegetative growth of Cycas plants as affected by Arbuscular Mycorrhizal fungi (AMF), Actosol (Acto.) and mineral fertilization (NPK) in the two growing seasons included data pertaining to leaves [length $(\mathrm{cm})$, petiole length $(\mathrm{cm})$, width $(\mathrm{cm})$, number, pinnae number, fresh and dry weights plant $^{-1}(\mathrm{~g})$ ] .

\section{Length of leaves and petiole}

Data shown in Table (1) reveal that all treatments significantly increased length of leaves and petiole over control except for NPK as the differences were insignificant in 
both seasons. Moreover, the highest significantly values of length of leaves and petiole were found in inoculated plants by Arbuscular Mycorrhizal fungi (AMF) (41.00 and $39.67 \mathrm{~cm}$ leaves length, respectively) in both seasons. However, the second category was occupied by plants treated with Actosol (Acto.) (36.62 and $35.33 \mathrm{~cm}$ leaves length, respectively) and the differences were significant compared with the other treatments used in both seasons. Concerning the effect of the combinations, data in Table (1) clearly indicate that the best results were recorded with plants treated with Actosol (Acto.) +AMF (38.50 and 36.33cm leaves length in the two seasons, respectively). Moreover, it can be noticed from Table (1) that NPK combined with either AMF or Actosol (Acto.) significantly enhanced the length of leaves and petiole compared with NPK alone in both seasons. These results are in harmony with those of Eliwa et. al. (2009) on Iris tingitana who stated that humic acid improved plant height. Meanwhile, the increase in plant height due to microorganisms of biofertilizer can be attributed to the capability of those microorganisms in inducing beneficial effects on plant growth by contributing hormones such as cytokinins or auxins (Bouton et. al., 1985).

\section{Leaves width $(\mathrm{cm})$}

Evidently, data in Table (1) show that plants inoculated by the Arbuscular Mycorrhizal fungi (AMF) increased leaves width over control and other fertilizers treatments (19.67 and $18.30 \mathrm{~cm}$ in the two seasons, respectively). However, applying Actosol (Acto.) induced also leaves width over control and NPK (16.67 and $16.00 \mathrm{~cm}$, respectively) in both seasons. Regarding data of the combinations shown in Table (1) pointed out that the highest values of leaves width were found with Actosol (Acto.) +AMF (18.62 and18.80 cm in both seasons, respectively). These results can be attributed the promoting effect of biofertilizer treatment on leaves width which accelerates cell division (Brunetti et. al., 2006). Scagel (2004) on Harlequin stated that mycorrhizal fungi promoted plant development growth.

\section{Number of leaves and Pinnae plant ${ }^{-1}$}

It is obvious from data presented in Table (1) that all treatments increased the leaf numbers plant ${ }^{-1}$ (which ranged between 4.00 to 7.00 in $1^{\text {st }}$ season and 5.00 to 6.80 in $2^{\text {nd }}$ one) and pinnae number plant ${ }^{-1}$ (which ranged between 33.20 to 41.00 in $1^{\text {st }}$ season and 32.50 to 38.67 in $2^{\text {nd }}$ one more than control (3.33 and 3.67 for leaves number and 30.00 and 27.33 for pinnae number plant ${ }^{-1}$ in both seasons, respectively). In this respect, the maximum increment in leaf formation was obtained when the seedlings were inoculated with Arbuscular Mycorrhizal fungi (AMF) followed by those treated with Actosol (Acto.) in both seasons. As for the effect of the combinations, the 
highest estimation of number of leaves and pinnae number plant ${ }^{-1}$ were recorded from plants treated with Actosol (Acto.) +AMF in the two seasons. Also, the addition of NPK to either AMF or Actosol (Acto.) led to an increment in number of leaves plant ${ }^{-1}$ compared with NPK alone in both seasons. In this regard, the pronounced effect of fertilization with Arbuscular Mycorrhizal fungi (AMF) and Actosol (Acto.) treatments may be related to the improving effect on soil structure, aeration, water retention and uptake of nutrients from the soil. Moreover, they increase microbial activity in the soil and enhance plant cell biomass. The low molecular weight humics in Actosol have the cytokinnin / auxin like response and not only help in transport of trace elements, but also greatly stimulate vegetative growth (Putti et. al., 1988). However, the great influence of Actosol on vegetative growth parameters was confirmed by many authors on different plant species. El- Khateeb et. al. (2010) found that the use of humic acid and Mycorrhizae on Calia secundiflora gave the maximum number of leaves and branches per plant.

\section{Fresh and dry weights of leaves plant $^{-1}(\mathrm{~g})$}

As shown in Table (1) all treatments significantly increased fresh weight of leaves compared with control in both seasons, with the significantly superiority of using Arbuscular Mycorrhizal fungi (AMF) giving 51.80 and 55.36 (g) in both seasons, respectively. Actosol (Acto.) treatment showed also marked increase in this concern in both seasons. Regarding the effect of the combinations, it is clear from the data that the greatest increment was obtined with the treatment of Actosol (Acto.) +AMF in the two seasons. As for the effects of NPK as well as the biostimulants treatments on dry weight of leaves, it is clear that they were in parallel with their effects on fresh weight of leaves. Arbuscular Mycorrhizal fungi (AMF) as well as actosol (Acto.) treatments were the most effective. The increase in leaves fresh and dry weights can be attributed to the increase in both plant height and number of leaves /plant. The increment in growth of leaves by treating the plants with humic acid may be attributed to humic acid contain many elements which in turn improve the plant growth. These results are in harmony with those reported by some researchers who reported that soil inoculation with Mycorrhizae leads to best seedling growth and nutrients uptake (Phanuphong and Gregory, 2003).

\section{ח-Root parameters}

Beneficial effects were scored on roots length due to using NPK and the biostimulants treatments in both seasons, with the mastery of Arbuscular Mycorrhizal fungi (AMF) followed by Actosol (Acto.) treatment in elevating the values more than the control and other treatments used $(T a b l e, 1)$. It was noticed that the presence of 
AMF with actosol (Acto.) recorded the highest values of root length compared with the other combinations treatments in both seasons. In this respect, the low molecular weight humics in Actosol have the cytokinnin/ auxin like response greatly stimulate root growth (Putti et. al., 1988). Also, these data may be attributed to the role of mycorrhizal fungi which improved plant growth as recorded in many crops through enhancing root growth and function (Westphal et. al., 2008). A similar trend was observed on fresh and dry weights of roots as affected by NPK as well as the biostimulants treatments. Receiving Arbuscular Mycorrhizal fungi (AMF) and Actosol (Acto.) treatments proved their mastery in increasing the fresh and dry weights of roots values. Meanwhile, the combination treatment of Actosol (Acto.) +AMF had the heaviest fresh and dry weights of roots (Table, 1). In conclusion, the increment in root length, fresh and dry weights due to using biofertilizer treatments or their combinations with organic fertilizer may be due to both plant hormones and nitrogen fixation produced from biofertilizer organisms. Similar results were obtained by ElKhateeb et al (2010) who found that the use of humic acid and Mycorrhizae on Calia secundiflora were the most effective on increasing the root length, fresh and dry weights. 
Table 1. Effect of Actosol, AM fungi and NPK either single or in combination on some vegetative and roots characteristics of Cycas revoluta during two successive seasons (2010\&2011).

\begin{tabular}{|c|c|c|c|c|c|c|c|c|c|c|}
\hline \multicolumn{11}{|l|}{$1^{\text {st }}$ season } \\
\hline \multirow[b]{2}{*}{ Treatments } & \multirow[b]{2}{*}{$\begin{array}{l}\text { Length } \\
\text { (cm) }\end{array}$} & \multicolumn{4}{|c|}{ Leaves } & \multirow[b]{2}{*}{$\begin{array}{l}\text { D.W. } \\
\text { (g) }\end{array}$} & \multirow{2}{*}{$\begin{array}{l}\text { Pinnae } \\
\text { number }\end{array}$} & \multirow[b]{2}{*}{$\begin{array}{l}\text { Length } \\
\text { (cm) }\end{array}$} & \multicolumn{2}{|l|}{ Roots } \\
\hline & & $\begin{array}{l}\text { Width } \\
(\mathrm{cm})\end{array}$ & $\begin{array}{c}\text { Petiole } \\
\text { length } \\
(\mathrm{cm})\end{array}$ & No. & $\begin{array}{l}\text { F.W. } \\
\text { (g) }\end{array}$ & & & & $\begin{array}{l}\text { F.W. } \\
\text { (g) }\end{array}$ & $\begin{array}{l}\text { D.w. } \\
\text { (g) }\end{array}$ \\
\hline Control & 28.40 & 13.00 & 11.80 & 3.33 & 29.21 & 2.10 & 30.00 & 16.80 & 2.20 & 0.68 \\
\hline NPK & 30.17 & 15.00 & 14.20 & 4.00 & 37.45 & 4.11 & 33.20 & 17.80 & 2.67 & 0.96 \\
\hline Actosol (Acto.) & 36.62 & 16.67 & 17.50 & 5.00 & 43.50 & 5.18 & 36.00 & 24.00 & 3.87 & 1.29 \\
\hline AM fungi (AMF) & 41.00 & 19.67 & 19.00 & 7.00 & 51.80 & 8.16 & 41.00 & 27.20 & 4.34 & 1.35 \\
\hline 1/2 NPK + Acto. & 35.27 & 16.00 & 16.00 & 5.67 & 45.30 & 6.25 & 36.60 & 23.30 & 3.28 & 1.07 \\
\hline $1 / 2 N P K+A M F$ & 34.50 & 18.00 & 17.50 & 5.00 & 47.51 & 7.48 & 35.67 & 24.80 & 3.65 & 1.24 \\
\hline Acto. + AMF & 38.50 & 18.62 & 17.80 & 6.71 & 49.08 & 7.80 & 37.32 & 26.00 & 3.82 & 1.27 \\
\hline L.S.D. $\quad 0.05$ & 3.75 & 3.36 & 3.39 & 3.37 & 4.76 & 4.45 & 3.65 & 3.67 & 3.57 & 1.12 \\
\hline \multicolumn{11}{|l|}{$2^{\text {nd }}$ season } \\
\hline Control & 27.00 & 14.15 & 10.60 & 3.67 & 31.12 & 3.70 & 27.33 & 18.60 & 1.70 & 0.87 \\
\hline NPK & 29.00 & 15.40 & 13.50 & 5.00 & 39.31 & 4.80 & 32.50 & 20.60 & 2.89 & 0.98 \\
\hline Actosol (Acto.) & 35.33 & 16.00 & 16.64 & 6.00 & 46.62 & 6.39 & 35.33 & 23.00 & 3.28 & 1.05 \\
\hline AM fungi (AMF) & 39.67 & 18.30 & 18.15 & 6.80 & 55.36 & 9.13 & 38.67 & 26.30 & 4.08 & 1.28 \\
\hline 1/2 NPK + Acto. & 35.00 & 15.07 & 15.80 & 5.72 & 49.08 & 7.10 & 36.70 & 22.00 & 3.20 & 1.03 \\
\hline $1 / 2$ NPK + AMF & 33.20 & 17.44 & 16.66 & 5.33 & 51.00 & 7.35 & 34.00 & 24.00 & 3.60 & 1.20 \\
\hline Acto. + AMF & 36.33 & 18.80 & 18.00 & 6.67 & 53.22 & 8.12 & 37.45 & 25.75 & 3.80 & 1.22 \\
\hline L.S.D. & 3.69 & 3.70 & 3.47 & 3.64 & 4.57 & 3.70 & 3.47 & 3.68 & 3.07 & 1.25 \\
\hline
\end{tabular}

Ш- Chemical composition as affected by AM fungi, Actosol (Acto.), NPK and their combinations

Results of Table (2) show the increment of chlorophyll (a) and (b) accumulation in leaves associated with the different fertilizer treatments compared with the control in both seasons. However, the promoting action was more obvious with applying Arbuscular Mycorrhizal fungi (AMF) followed by Actosol (Acto.) treatments in the two seasons. However, a favorable influence was detected due to receiving the combinations which reached the highest effect with plants treated with Actosol (Acto.) +AMF in the two seasons. The aforementioned findings are in harmony with El- Attar (2006) on Ficus alii, stated that humic acid significantly increased chlorophylls content. Regarding the effect on the content of carotenoids, a clear increment on carotenoids accumulation in leaves was detected with control treatment $(0.52$ and $0.46 \mathrm{mg} / \mathrm{g}$ F.W., respectively in both seasons) as compared to other treatment. Whereas, supplying the plants Arbuscular mycorrhizal fungi (AMF) followed by Actosol (Acto.) treatments as well as the combination of them behaved the contrary action. Such treatments declined the values of carotenoids in the two seasons. In this connection, 
El- Khateeb et. al. (2010) found that the use of humic acid and mycorrhizae on Calia secundiflora decrease the leaves content of carotenoids.

Regarding total carbohydrates \% in leaves, as shown in table (2) plants inoculated with Arbuscular Mycorrhizal fungi (AMF) considerably increased total carbohydrates \% in leaves comparing with control and other treatments (26.50 and $26.91 \%$, respectively) in both seasons. Also, great influence was observed on the obtained values as a result of supplying the plants Actosol (Acto.) (24.66 and 25.92, respectively) followed by the combination treatment of Actosol (Acto.) +AMF in both seasons. The other fertilizer treatments revealed also an increment but with less effect on total carbohydrates content. Referring to the increment on total carbohydrates content in leaves due to Arbuscular Mycorrhizal fungi (AMF) and Actosol (Acto.), El- Attar (2006) on Ficus alii found that humic acid increased the accumulation of total carbohydrates in the different plant parts. El- Khateeb et. al. (2010) found that the use of humic acid and Mycorrhizae on Calia secundiflora increase the leaves content of total carbohydrates.

As for the mineral analysis, data in Table (3) revealed a clear increment in nitrogen, phosphorus and potassium accumulation in leaves as response to the different fertilizer treatments so as to reach their maximum records with the treatment of inoculation by AMF followed by Actosol (Acto.) in the two seasons. Whereas, receiving the plants NPK recorded the lowest values in this concern. In addition, applying the combinations increased nitrogen accumulation revealed their superiority with the treatment of Actosol (Acto.) +AMF in both seasons. These results are supported by the obtained data results of Dubey and Ginwal (1997) reported that Mycorrhizae increased the absorption area of the roots and provide host plants with nutrients. Mycorrhizae improves the uptake of nutrients. Humic acid has been shown to increase the uptake of nitrogen utilization efficiency, it also enhances the uptake of potassium, calcium, magnesium and phosphorus (Watfa, 2009).This goes in harmony with researches on ficus alii stating that humic acid had a great effect in increasing the N, P and K contents of the plants [Phanuphong and Gregory (2003), El- Attar (2006)]. 
Table 2. Effect of Actosol, AM fungi and NPK either single or in combination on total carbohydrates $\%$ and photo synthetic pigments content in leaves of Cycas revoluta during two successive seasons (2010\&1011).

\begin{tabular}{|l|c|c|c|c|c|c|c|c|}
\hline Control & 16.67 & 17.73 & 0.88 & 0.66 & 0.30 & 0.32 & 0.52 & 0.46 \\
\hline NPK & 21.33 & 22.08 & 1.02 & 0.89 & 0.39 & 0.38 & 0.44 & 0.41 \\
\hline $\begin{array}{l}\text { Actosol } \\
\text { (Acto.) }\end{array}$ & 24.66 & 25.92 & 1.19 & 1.29 & 0.51 & 0.49 & 0.38 & 0.40 \\
\hline $\begin{array}{l}\text { AM fungi } \\
\text { (AMF) }\end{array}$ & 26.50 & 26.91 & 1.28 & 1.45 & 0.55 & 0.52 & 0.29 & 0.37 \\
\hline $\begin{array}{l}1 / 2 \quad \text { NPK } \\
+ \text { Acto. }\end{array}$ & 24.30 & 24.08 & 1.18 & 1.14 & 0.40 & 0.42 & 0.35 & 0.39 \\
\hline $\begin{array}{l}1 / 2 \text { NPK } \\
+ \text { AMF }\end{array}$ & 25.09 & 24.97 & 1.16 & 1.10 & 0.42 & 0.44 & 0.30 & 0.36 \\
\hline $\begin{array}{l}\text { Acto.+ } \\
\text { AMF }\end{array}$ & 26.90 & 25.52 & 1.22 & 1.19 & 0.54 & 0.45 & 0.31 & 0.37 \\
\hline
\end{tabular}

Table 3. Effect of Actosol, AM fungi and NPK either single or in combination on $\mathbf{N}, \mathbf{P}$ and $K \%$ in leaves of Cycas revoluta during two successive seasons (2010\&1011).

\begin{tabular}{|l|l|l|l|l|l|l|}
\hline Control & 1.20 & 1.18 & 0.20 & 0.25 & 1.45 & 1.38 \\
\hline NPK & 1.64 & 1.86 & 0.33 & 0.35 & 2.54 & 2.58 \\
\hline Actosol (Acto.) & 2.29 & 2.19 & 0.35 & 0.38 & 2.61 & 2.67 \\
\hline AM fungi (AMF) & 2.58 & 2.32 & 0.39 & 0.41 & 2.77 & 2.80 \\
\hline $1 / 2$ NPK + Acto. & 2.11 & 2.08 & 0.34 & 0.35 & 2.60 & 2.64 \\
\hline $1 / 2$ NPK + AMF & 2.21 & 2.27 & 0.36 & 0.38 & 2.63 & 2.72 \\
\hline Acto. + AMF & 2.36 & 2.30 & 0.37 & 0.39 & 2.65 & 2.76 \\
\hline
\end{tabular}




\section{REFERENCES}

1. Bouton, J. H., S.L. Albrecht and D. A. Zuberer. 1985. Screening and selection of pearl millet for root associated bacterial nitrogen fixation. Field Crops Res., 11:131-140.

2. Brunetti, G., P. Cesar and C. Charles. 2006. Compositional and functional features of humic acids from organic amendments and amended soils in Minnesota. J. Soils Biology and Biochemist., 3: 20-26.

3. Dubey, R. C. and H.S. Ginwal. 1997. Prospects of Mycorrhizael fungi in the Himalaya Forms, Function and Management. Himalayan Microbial Diversity Part 2. Today and Tomorrow's Printers and Publ., New Delhi, p: 317-338.

4. El- Khateeb, M.A., A. A. Nasr, A.N. Fahmy and A.H.H. Dorgham. 2010. Effect of $\mathrm{GA}_{3}$ and growth biostimulants on growth and chemical composition of Calia secundiflora plants. Journal of Horticultural Science \& Ornamental Plants, 2(2): 118-124.

5. El-Attar, A. 2006. Physiological studies on Ficus alli plants. M.Sc. Thesis, Faculty of Agric., Cairo Univ.

6. Eliwa, N.Y., B. B. Rezk Alla and M. A. El-Shamy. 2009. Effect of organic and biofertilizer treatments on growth, flowering, bulb production and chemical constituents of Iris tingitana cv. Wedgewood plants. J. Boil. Chem. Environ. Sci., 4(2): 441-461.

7. Gerdemann, G.W. and T. H. Nicolson. 1963. Spores of mycorrhizal endogone species extracted from soil by wet- sieving and decanting. Trans. Brit. Mycol Soc., 46: 235-244.

8. Herbert, D., P.J. Philips and R.E. Strange. 1971. Determination of total carbohydrates. Methods in Microbiol., 58: 209-344.

9. Jackson, M.L. 1973. Soil Chemical Analysis. Prentice. Hall, New Delhi., p: 219221.

10. Phanuphong, A. and T. Gregory. 2003. The effects of humic acids and phosphoric acids on grafted avocado rootstock. Proceeding $V$ World Avocado Congress. Mundial del Aguacate, p: 395-400.

11. Putti, A., F.R.Levi- Minzi., R. Riffald and G. Gudi. 1988. Liquid humic acid extracts and their uses in agriculture. An overview in Proceedings. Science, Technology and Utilization of Humic Acids, Conference held at CSIRO Division of Coal Technology (Australia) p: 96-105. 
12. Saleh, S. A, M. A. Nassef, F. T. Mikhaeel and A. A. E- Soud. 2008. Response of faba been (Vicia faba L.) to combined inoculation with Rhizobia, VA-mycorrizae and phosphate solubilizing bacteria under sandy soil conditions. Arab. Univ. J. Agric. Sci., Ain Shams Univ., Cairo, Egypt., 16(2): 309- 317.

13. Saric, M., R. Kastrori, R. Curic, T. Cupina and I. Geric. 1967. Chlorophyll determination. Univ. Unoven Sadu Parktikum is fizologize Bibjoke, Beagard, Haunca, Anjiga, p215.

14. Scagel C.F. 2004. Inoculation with -Arbuscular Mycorrhizal fungi and Rhizobacteria alters nutrient allocation and flowering of Harlequin flower. Hort.Technology, 14(1): $39-48$.

15. Snedecor, C.W. and W. G. Cochran. 1982. Statistical Methods. $7^{\text {th }}$ ed. The Iowa State Univ. Press Ames. Iowa, USA.

16. Stevenson, F.J. 1994. Humic Chemistry: Genesis, Composition, Reaction. $2^{\text {nd }}$ ed, John Wiley and Sons, Inc., New York.

17. Watfa, R. A. 2009. Effects of Soil media, nutrition and Mycorrhizae funfi on growth and chemical composition of carob and Aleppo pine seedlings. M.Sc. Thesis, Fac. Agric., Cairo Univ. p: 117-128.

18. Westphal, A., N. L. Snyder and L. Xing. 2008. Effects of inoculations with mycorrhizal fungi of soilless potting mixes during transplant production on watermelon growth and early fruit yield. HortScience, 43:286-583. 


\title{
إستجابة شتلات نبات السيكس (نخيل ذيل الجمل) لبعض الأسمدة الحيوية
}

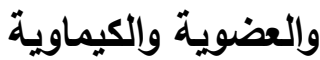



قسم بحوث نباتات الزينة و تنسيق الحدائق - معهد بحوث البساتين- مركز البحوث الزراعية- الجيزة-

أجريت تجربة أصص فى صوبة ساران بمثتل قسم بحوث نباتات الزينة و نتسيق الحدائق معهد بحوث البساتين بالجيزة- مركز البحوث الزراعية- جيزة- مصر خلال موسمى

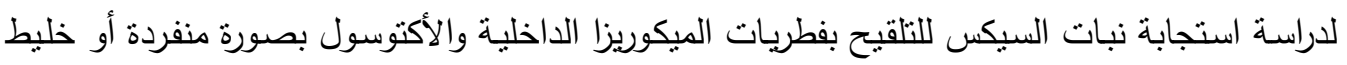


الكيماوى لنبات السيكس وقد أظهرت النتائج الأتى : - جميع معاملات التسميد كان لها تأثير منشط لمعظم الصفات التهات النباتية المدروسة مقا رنة بمعاملة



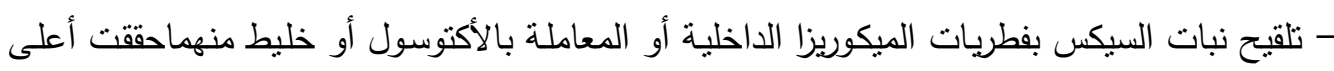

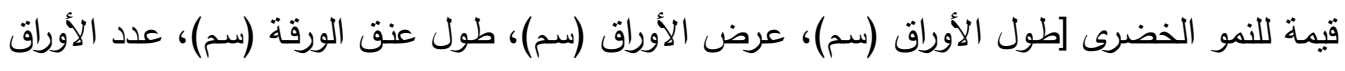





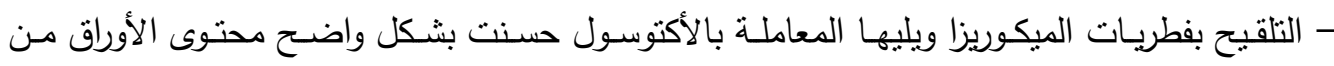
الكلوروفيل أ، ب والكاروتينويدات (مللجم / جم وزن طازج) كما حققت أعلى زيادة في النسبة المئوية

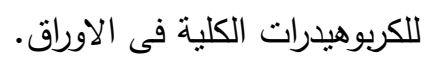
- أظهرت الننائج آن كل معاملات التسميد أدت إلى زيادة واضحة في النسبة المئوية لكل من النتروجين

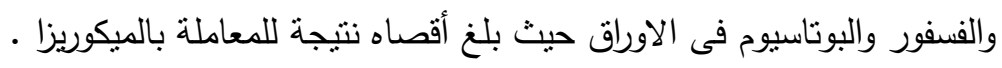

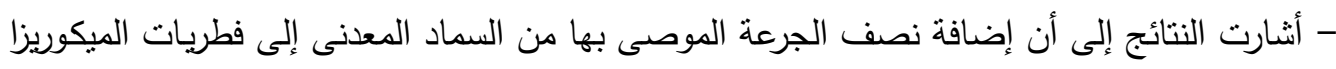

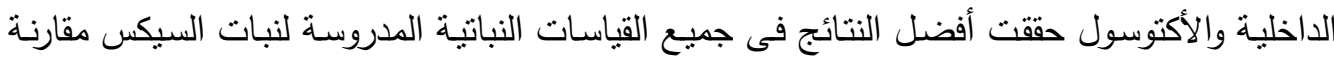


- بصفة عامة كانت السيادة فى جميع القياسـات السابقة نتيجة المعاملة بـالميكوريزا يليها المعاملة


الكلمات الدالة : نبات السيكس - فطر الميكوريزا- الأكتوسول- سماد معدنى. 